\title{
Onset of bronchodilation and finger tremor induced by salmeterol and salbutamol in asthmatic patients
}

\author{
Jan Lötvall MD PhD, Helen Lunde MD, Nils Svedmyr MD PhD \\ Department of Clinical Pharmacology, Sahlgrenska University Hospital, Göteborg, Sweden
}

\begin{abstract}
J Lötvall, H Lunde, N Svedmyr. Onset of bronchodilation and finger tremor induced by salmeterol and salbutamol in asthmatic patients. Can Respir J 1998;5(3):191-194.

Salmeterol is a beta-agonist with bronchodilator properties that last for at least $12 \mathrm{~h}$ after inhalation. However, the onset of action of salmeterol immediately after inhalation has not been sufficiently investigated. In the present study, the onset of action and tremor-inducing effect of two doses of inhaled salmeterol (50 and $100 \mu \mathrm{g}$ ) were compared with inhaled salbutamol (200 and $400 \mu \mathrm{g})$ and placebo. Lung function was measured using forced expiratory volume in $1 \mathrm{~s}(\mathrm{FEV})$, and tremor was measured using a linear accelerometer. With salbutamol there was rapid bronchodilation, both doses producing more than $15 \%$ improvement in mean FEV within 2 mins of inhalation. With salmeterol, on the other hand, significant bronchodilation was delayed until 7 mins versus placebo, and the full bronchodilation effect was not achieved until 60 mins after inhalation. There was a much more rapid onset of tremor with salbutamol $(400 \mu \mathrm{g})$ than salmeterol. There was a much slower onset of bronchodilation with salmeterol than salbutamol. Therefore, salmeterol cannot be recommended to relieve acute symptoms.
\end{abstract}

Key Words: Asthma, Bronchodiliation, Salbutamol, Salmeterol

\section{Déclenchement de la bronchodilatation et trem- blement des doigts induits par le salmétérol et le salbutamol chez des patients asthmatiques}

RÉSUMÉ: Le salmétérol est un bêta-agoniste doté d'un effet bronchodilatateur qui se prolonge au moins jusqu'à 12 heures après l'inhalation. Cependant, le début d'action du salmétérol immédiatement après l'inhalation n'a pas été étudié suffisamment. Dans la présente étude, le début d'action et l'effet de tremblement induit par deux doses de salmétérol en inhalation (50 et $100 \mu \mathrm{g}$ ) ont été comparés à deux doses de salbutamol en inhalation ( 200 et $400 \mu \mathrm{g}$ ) et un placebo. On a mesuré la fonction pulmonaire en utilisant le volume expiratoire maximum/seconde (VEMS), et le tremblement a été mesuré au moyen d'un accéléromètre linéaire. Avec le salbutamol, on a noté une bronchodilatation rapide ; les deux doses ont entraîné une amélioration de plus de $15 \%$ du VEMS moyen en moins de deux minutes suivant l'inhalation. Par contre, en ce qui concerne le salmétérol, une bronchodilatation significative ne s'est produite que 7 minutes après l'inhalation par rapport au placebo et l'effet bronchodilatateur maximal n'a été atteint que 60 minutes après l'inhalation. Le déclenchement du tremblement était beaucoup plus rapide avec le salbutamol $(400 \mu \mathrm{g})$ qu'avec le salmétérol. Le déclenchement de la bronchodilatation était beaucoup plus lent avec le salmétérol qu'avec le salbutamol. En conséquence, le salmétérol ne doit pas être recommandé pour soulager les symptômes d'asthme aigus.
$\mathrm{R}$ ecently, inhaled beta-agonists having a prolonged duration of action have been marketed for use in asthma. One of these beta-agonists, salmeterol, has a duration of action of at least $12 \mathrm{~h}$ after a single dose (1). A number of single-dose comparisons between salmeterol and shorter acting beta-agonists such as salbutamol have been reported (2-6) in both healthy individuals and asthmatics. Salmeterol has a substantially longer duration of action than shorter acting compounds such as salbutamol and terbutaline. In a study in normal subjects, salmeterol seemed to have a slower onset of action than salbutamol (2), and in single dose studies in asthmatic subjects, it has been shown that salmeterol has a slower onset of action than salbutamol and formoterol (3).

All beta-agonists, both long and short acting, produce skeletal muscle tremor when given by the inhaled route in high enough doses $(4,5)$. Clinically, it has been reported that terbutaline may have a more pronounced tendency to induce tremor than other agents after both oral and inhaled admini-

Correspondence: Dr Jan Lötvall, Department of Clinical Pharmacology, Sahlgrenska University S-413 45, Göteberg, Sweden. Telephone 011-46-31-60-29-67, fax 011 46-31-41-32-90, e-mail jan.lovtall.medfak.gu.se 
stration. The mechanism underlying such differences is not clear, but differences in the distribution of the drugs in the lung and absorption kinetics are two possible explanations.

The aim of this study was to evaluate the onset of action of two doses of salmeterol compared with two doses of salbutamol and placebo to extend previous studies to multiple-dose comparisons. Particularily, we wished to evaluate the tremor-inducing effects of each dose, with an objective method using a linear accelerometer (4). We selected the doses of 50 and $100 \mu \mathrm{g}$ salmeterol, which have been suggested to be equipotent to 200 and $400 \mu \mathrm{g}$ salbutamol, respectively, for bronchodilation $(1,6)$.

\section{PATIENTS AND METHODS}

This study was accepted by the ethics committee in Göteborg, Sweden, and the Swedish Medical Products Agency, Uppsala, Sweden. The study was also performed according to Good Clinical Trial Practice principles, and was monitored accordingly by the sponsor. The aim of the study was explained in detail to each patient, and patients were only included if they provided oral and written consent.

Patients: Asthmatic patients of either sex, between 20 and 70 years of age (inclusive), were included in the study. A reversibility of $15 \%$ to $50 \%$ in forced expiratory volume in $1 \mathrm{~s}$ $\left(\mathrm{FEV}_{1}\right) 15$ mins after inhalation of up to $400 \mu \mathrm{g}$ of salbutamol was required for inclusion. Exclusion criteria were significant cardiovascular disease (heart failure, cardiomyopathy, severe angina pectoris), uncontrolled diabetes mellitus, significant thyroid, hepatic or renal disease, known neuromuscular disease, pregnancy, hospitalization within 28 days or a lower respiratory tract infection, history of recent allergen exposure causing asthmatic symptoms, use of any investigational drug within 28 days previous to inclusion and use of beta-blockers. Patients were also interviewed and clinically examined at the inclusion visit. The aim at the beginning of the study was to recruit 12 patients who would complete the whole study.

Protocol: At each visit, the patients were given either salbutamol (200 or $400 \mu \mathrm{g}$ ), salmeterol (50 or $100 \mu \mathrm{g}$ ) or placebo (vehicle) in a double-blinded fashion, using a metered dose inhaler connected to a spacer. Patients were instructed not to take any anti-asthma medication in the morning of the visit to the clinic. Each study day was separated by at least two days, tests were started before noon, and the time of the study did not differ by more than two hours for each individual patient.

Lung function, assessed by $\mathrm{FEV}_{1}$, was measured by a spirometer connected to a Macintosh II computer via an interface, and calculated with customized software (MacSpiro, Collingwood Measurement, United Kingdom). FEV 1 was measured before and at 2, 7, 15, 25, 45, 60, 90 and 120 mins after the inhalation of each dose of drug. Tremor was measured objectively $(4,5)$, using a linear accelerometer (Grass Instruments, Rhode Island) connected to an analogue digital board in a Macintosh computer and calculated with software developed in LabView (National Instruments, Texas). Tremor was measured 15, 45, 90 and 120 mins after the ad- ministration of study drug, and the change in tremor was calculated as a tremor ratio (the measured tremor divided by the baseline measurement for the day). The baseline FEV 1 before the administration of drugs was not allowed to vary more than $15 \%$ between each visit.

Regular treatment with inhaled glucocorticoids was acceptable, but needed to be stable for at least two weeks before inclusion, and treatment was continued unmodified throughout the study. Oral beta-agonist or oral slow release theophylline was not allowed in the $20 \mathrm{~h}$ before administration of study drugs. Salmeterol was not to be taken within $36 \mathrm{~h}$ of the study visit. No other anti-asthma drugs were allowed within $8 \mathrm{~h}$. If a patient had taken any short-acting beta-agonist less than $8 \mathrm{~h}$ before the visit to the clinic, the study day was cancelled and a separate study day was planned. Study drugs were supplied by Glaxo Group Research, London, United Kingdom.

Data analysis: A nonparametric test (Friedman's test) was used to determine any difference among treatments for each parameter and time point. If a significant variance was found, a Wilcoxon test was performed to test for significance between individual treaments. A standard statistical package (StatView, California) and a Macintosh computer was used for the tests.

\section{RESULTS}

Sixteen patients, 24 to 64 years of age, were included in the study, but four patients had to be excluded during the course of the study, due to improvement in basal lung function greater than $15 \%$ compared with the inclusion visit. The 12 patients who completed the study (nine females), had a mean baseline $\mathrm{FEV}_{1}$ of 2.48 (SEM 0.31; range 1.12 to 4.62), and a mean reversibility of $20.3 \%$ (SEM 1.3; range 15 to 27). All patients except one used inhaled glucocorticoids (mean dose $727 \mathrm{mg}$, range 0 to 1600 )

Friedman's test showed a significant variance for percentage change in $\mathrm{FEV}_{1}$ after the different treatments $(\mathrm{P}<0.001)$. All doses of salmeterol and salbutamol produced significant improvement in $\mathrm{FEV}_{1}$ compared with placebo $(\mathrm{P}<0.003$ for all treatments; Figure 1 top). Salmeterol $50 \mu$ g produced a significantly smaller maximal improvement in $\mathrm{FEV}_{1}$ than $100 \mu \mathrm{g}$ (Figure 1 bottom; $\mathrm{P}<0.03$ ), and a numerically smaller maximal improvement in $\mathrm{FEV}_{1}$ than either dose of salbutamol. This smaller maximal improvement in $\mathrm{FEV}_{1}$, however, was not statistically significant $(\mathrm{P}=0.11$ and $\mathrm{P}=0.06$ compared with 200 and $400 \mu \mathrm{g}$ salbutamol, respectively). Salbutamol had a very rapid onset of action by more than $\pm 15 \%$ mean improvement in $\mathrm{FEV}_{1}$ by 2 mins of inhalation (Figure 1 bottom). Salmeterol, on the other hand, had a significantly slower onset of action than salbutamol, with less bronchodilation achieved at 25 mins after $50 \mu \mathrm{g}$ compared with $200 \mu \mathrm{g}$ salbutamol (Figure 1 bottom; $\mathrm{P}<0.003$ ).

Friedman's test showed a significant variance for the tremor ratio after the different treatments $(\mathrm{P}<0.001)$. Salmeterol $100 \mu \mathrm{g}$, and salbutamol 200 and $400 \mu \mathrm{g}$ produced a significant increase in tremor compared with placebo, but salmeterol $50 \mu \mathrm{g}$ did not (Figure 2 top; $\mathrm{P}=0.012, \mathrm{P}=0.008$, 

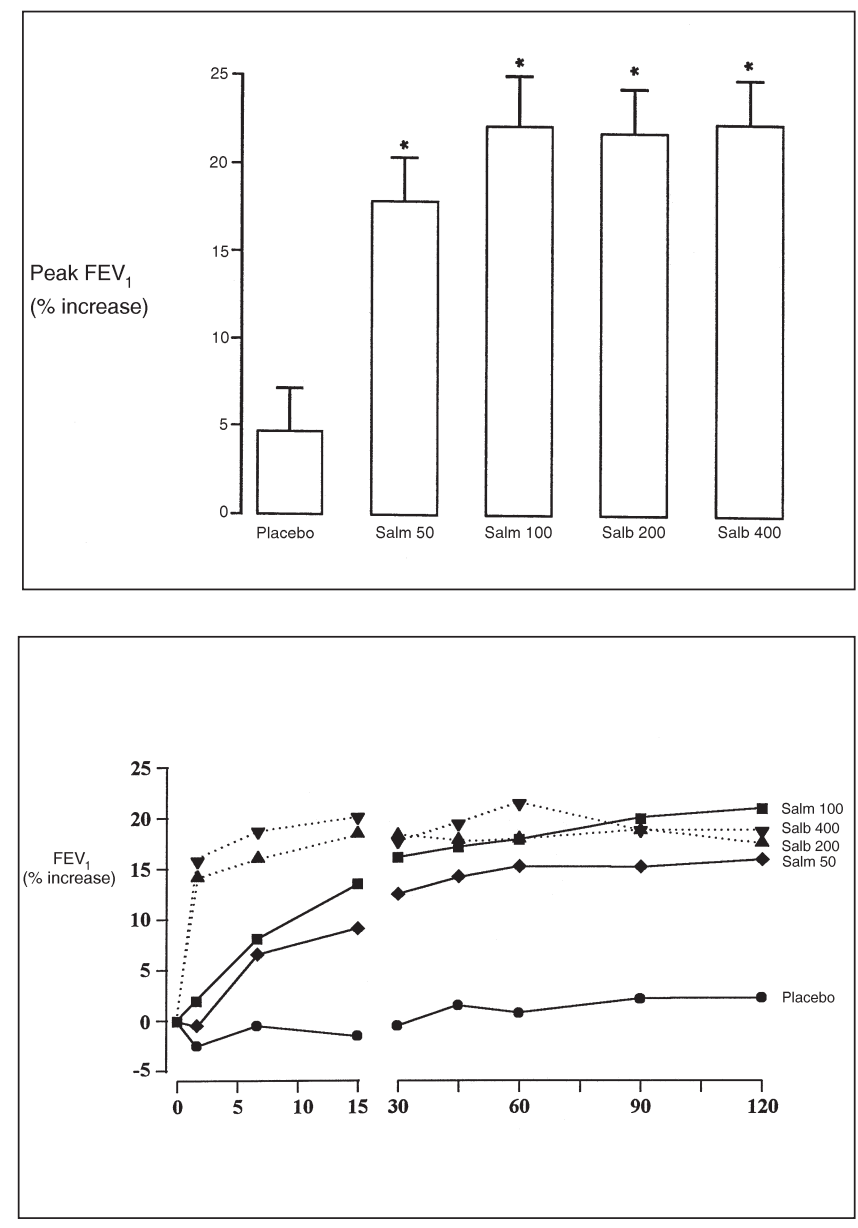

Figure 1) Top Maximal percentage change in forced expiratory volume in $1 \mathrm{~s}\left(F E V_{1}\right)$ after single inhaled doses of salmeterol (Salm) (50 or $100 \mu \mathrm{g}$ ), salbutamol (Salb) (200 and $400 \mu \mathrm{g}$ ) or placebo. Data are shown as mean \pm SEM. $* P<0.005$ versus placebo. Bottom Time-course up to 120 mins of changes in FEV l after single inhaled doses of salmeterol (50 or $100 \mu \mathrm{g}$ ), salbutamol (200 and $400 \mu \mathrm{g})$ or placebo. Data are shown as mean \pm SEM.

$\mathrm{P}=0.002$ and $\mathrm{P}=0.27$, respectively). The maximal tremorinducing effect of salbutamol $200 \mu \mathrm{g}$ was not significantly different from that of salmeterol $50 \mu \mathrm{g}(\mathrm{P}=0.27)$. In a comparison between the higher doses of the two drugs, the greater tremor inducing effect of salbutamol (Figure 2) almost reached statistical significance $(\mathrm{P}=0.06)$. The onset of tremor following use of salbutamol and salmeterol are shown in Figure 2. Salbutamol $400 \mu \mathrm{g}$ had a more rapid onset of action than either dose of salmeterol (Figure 2 bottom). One patient reported tremors as an adverse event after salmeterol $100 \mu \mathrm{g}$, and three patients after salbutamol $400 \mu \mathrm{g}$.

\section{DISCUSSION}

In this study, we have confirmed that salmeterol has a slower onset of bronchodilation than salbutamol. A dosedependent tremor-inducing effect of both salbutamol and salmeterol was found, the effect for salmeterol being much slower in onset.

In two earlier studies, salmeterol 50 and salbutamol $200 \mu \mathrm{g}$ were found to be approximately equipotent for maxi-
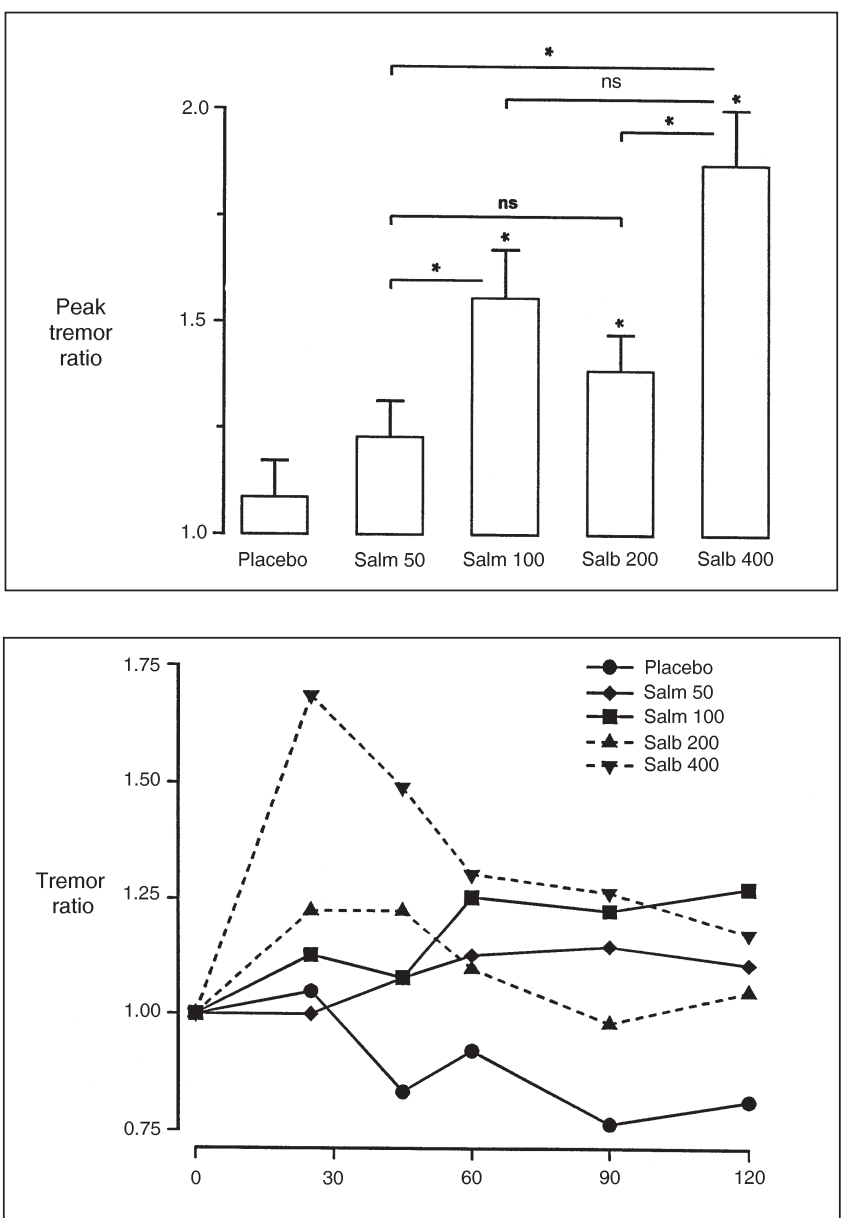

Figure 2) Top Maximal tremor ratio after single inhaled doses of salmeterol (Salm) (50 or $100 \mu \mathrm{g}$ ), salbutamol (Salm) (200 and 400 $\mu \mathrm{g})$ or placebo. Data are shown as mean \pm SEM. $* P<0.05$ versus placebo. Bottom Time-course up to 120 mins of the tremorinducing after single inhaled doses of salmeterol (50 or $100 \mu \mathrm{g}$ ), salbutamol (50 or $100 \mu \mathrm{g}$ ) or placebo. Data are shown as mean \pm SEM.

mal improvement in lung function (1). In this study, we found that both doses of salbutamol, and the higher dose of salmeterol, produce similar and probably close to maximal bronchodilation. We were able to document that the lower dose of salmeterol $(50 \mu \mathrm{g})$ was significantly less effective than the higher dose of salmeterol $(100 \mu \mathrm{g})$, and there was a tendency towards a smaller effect of this dose of salmeterol compared with both doses of salbutamol. Thus, our results suggest that the four times higher potency of salmeterol than salbutamol, proposed by earlier studies, may be an overestimate, and that the differences in potency probably are smaller. In a complex study design, Smyth and colleagues (7) performed a dose-response study comparing salbutamol with salmeterol, and suggested that salmeterol was up to 10 times more potent than salbutamol weight for weight. Thus, in contrast to our present data, it was proposed that salmeterol $50 \mu \mathrm{g}$ was equipotent to $500 \mu \mathrm{g}$ salbutamol, especially concerning improvement in FEV 1 . However, the comparision of doseequivalence was between a single dose of salmeterol and cumulative doses of salbutamol, and we would argue that this 
comparison is not valid because of the different protocols used for the two drugs.

The slower onset of action of salmeterol is consistent with a previous study (8), where it was found that reversal of methacholine-induced bronchoconstriction was slower for salmeterol than salbutamol. This finding also appears consistent with older studies that suggested a slower onset of bronchodilation with salmeterol $(1,9)$. The slower bronchodilator properties strengthen the recommendation that salmeterol should not be used as rescue medication in asthma. However, it is clear that the bronchodilator properties of both salmeterol and salbutamol are maintained during long term treatment with salmeterol (9-11).

In two previous studies $(1,7)$, only a very high dose of salmeterol $(200 \mu \mathrm{g})$ was found to produce subjective tremor. In the present study, three patients experienced tremor after $400 \mu \mathrm{g}$ salbutamol, whereas only one patient experienced

\section{REFERENCES}

1. Ullman A, Svedmyr N. Salmeterol, a new long acting inhaled $\beta_{2}$-adrenoceptor agonist: comparison with salbutamol in adult asthmatic patients. Thorax 1988;43:674-8.

2. Spring J, Clague J, Ind PW. A comparison of the effect of salmeterol and salbutamol in normal subjects. Br J Clin Pharmacol 1992;33:139-41.

3. van Noord JA, Smeets JJ, Raijmakers JA, Bommers AM, Maesen FP. Salmeterol versus formoterol in patients with moderately severe asthma; onset and duration of action. Eur Respir J 1996;9:1684-8.

4. Thiringer G, Svedmyr N. Evaluation of skeletal muscle tremor due to bronchodilator agents. Scand J Respir Dis 1975;56:93-102.

5. Larsson S, Svedmyr N. Tremor caused by sympathomimetics is mediated by beta2-adrenoreceptors. Scand J Respir Dis 1977;58:5-10.

6. Britton MG, Earnshaw JS, Palmer JBD. A twelve month comparison of salmeterol with salbutamol in asthmatic patients. Eur Respir J 1992;5:1062-7.

7. Smyth ET, Pavord ID, Wong CS, Wisniewski AF, Williams J, tremor after $100 \mu \mathrm{g}$ salmeterol, further implying a weak tremor-inducing effect of clinically used doses of salmeterol (12). However, in a previous study that was not placebo controlled (1), a dose-related tremor-inducing effect of salmeterol at doses of 100 and $200 \mu \mathrm{g}$ was observed, evaluated objectively with an accelerometer. In the present study, both doses of salbutamol and the higher dose of salmeterol produced a significantly increased tremor ratio than placebo, but a much more rapid onset of the tremor was observed with salbutamol. This rapid onset of the tremor may be important for inducing subjective experience. However, larger studies would be required to evaluate further any differences between salbutamol and salmeterol regarding this side effect.

ACKNOWLEDGEMENT: This study was sponsored by Glaxo Sweden AB.

Tattersfield A. Interaction and dose equivalence of salbutamol and salmeterol in patients with asthma. Br Med J 1993;306:543-5.

8. Beach JR, Young CL, Stenton SC, Avery AJ, Walters EH, Hendrick DJ. A comparison of the speeds of action of salmeterol and salbutamol in reversing methacholine-induced bronchoconstriction. Pulm Pharmacol, 1992;5:133-5.

9. Pearlman DS, Chervinsky P, LaForce C, et al. A comparison of salmeterol with albuterol in the treatment of mild-to-moderate asthma. N Engl J Med, 1992;327:1420-5.

10. Ullman A, Hedner J, Svedmyr N. Inhaled salmeterol and salbutamol in asthmatic patients. An evaluation of asthma symptoms and the possible development of tachyphylaxis. Am Rev Respir Dis 1990;142:571-5.

11. Lötvall J, Lunde H, Ullman A, Tornqvist H, Svedmyr. Twelve months, treatment with inhaled salmeterol in asthmatic patients. Effects on $\beta_{2}$-receptor function and inflammatory cells. Allergy 1992;47:477-83.

12. Maconchie JG, Forster JK. Dose-response study with high-dose inhaled salmeterol in healthy subjects. Br J Clin Pharmacol 1992;33:342-5. 


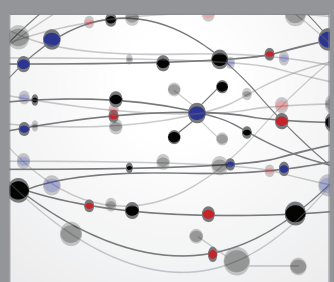

The Scientific World Journal
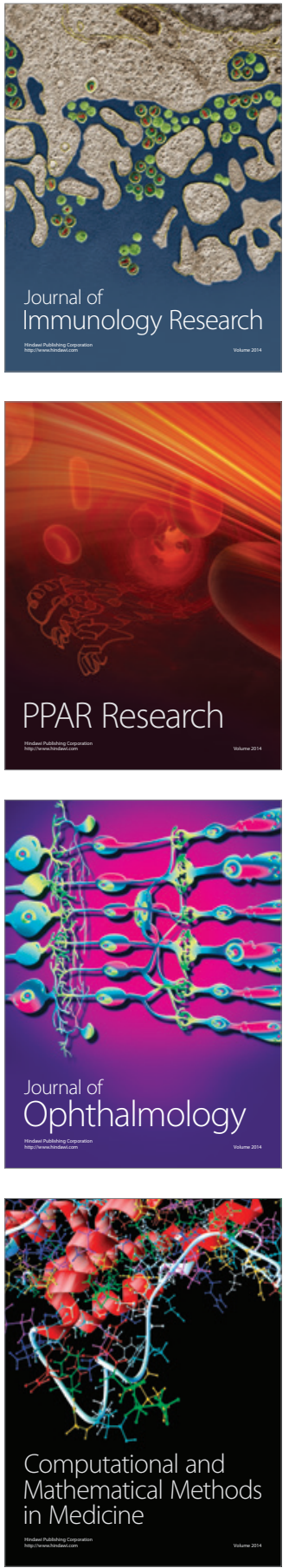

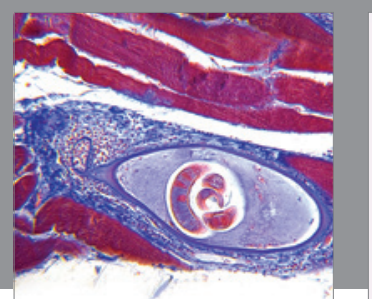

Gastroenterology Research and Practice

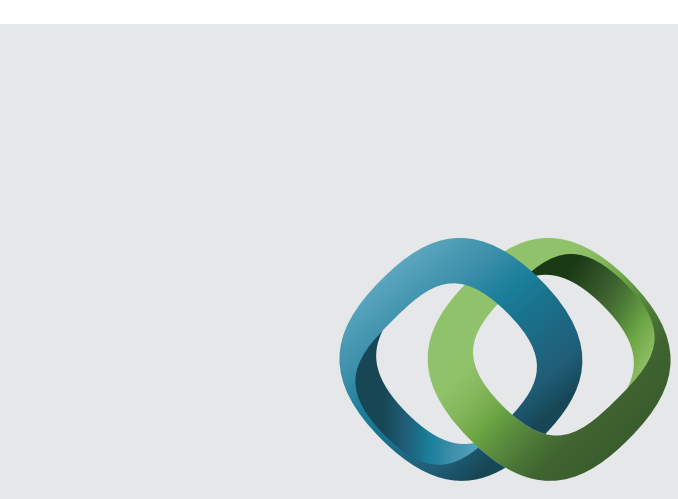

\section{Hindawi}

Submit your manuscripts at

http://www.hindawi.com
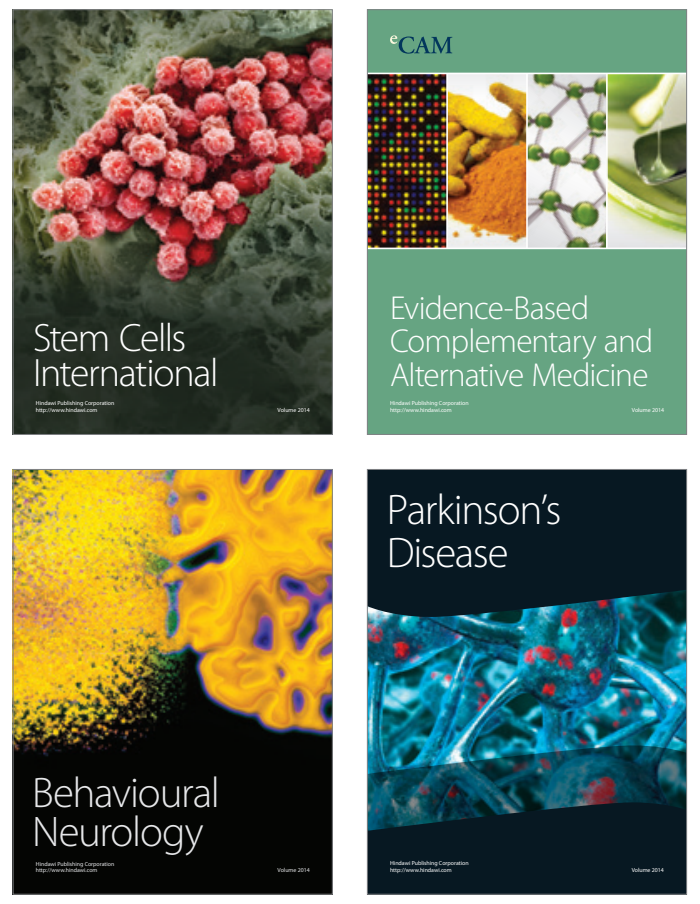
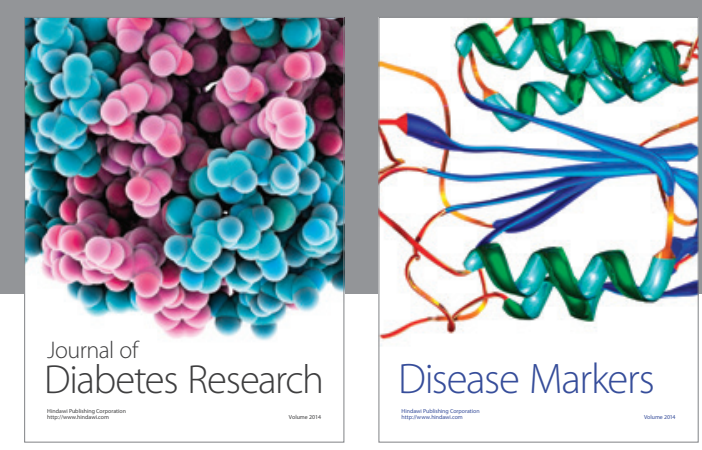

Disease Markers
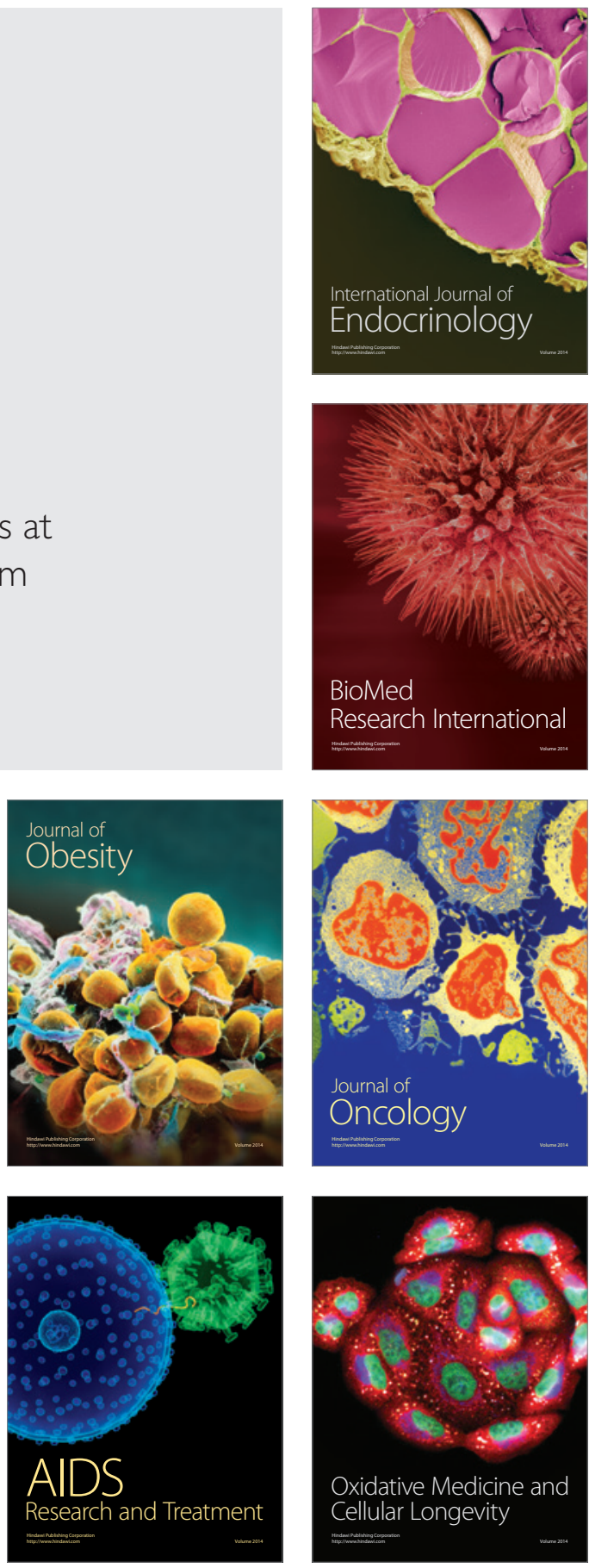